\title{
DETERMINATION OF HEATING AND COOLING DEGREE-DAY VALUES AND HEATING AND COOLING-DAYS IN BROILER HUSBANDRY: CENTRAL ANATOLIAN CASE
}

\author{
Atilgan Atilgan ${ }^{1}$, Ali Yucel $^{2}$, Burak Saltuk ${ }^{3}$ \\ ${ }^{1}$ Suleyman Demirel University, Turkey; ${ }^{2}$ Osmaniye Korkut Ata University, Turkey; \\ ${ }^{3}$ Siirt University, Turkey \\ atilganatilgan@sdu.edu.tr, aliyucel@osmaniye.edu.tr, bsaltuk@siirt.edu.tr
}

\begin{abstract}
The general aim of barns is to create suitable environments for animals against adverse weather conditions. Barns should be designed in such a way as to minimize the effect of weather changes and keep indoor conditions at the values of animals' desire. It is observed that the energy costs of unsuitable barns are high and the efficiency is not at the expected levels. Degree-day methods can be used to obtain information about the energy needs of any building. With this method, measurement values or meteorological data can be informed about the heating and cooling energy quantities of buildings. However, depending on the climate change in recent years, the climate changes that have taken place in order to provide optimum comfort in the barns should be examined. For this purpose, the Central Anatolia Region covering 13 provinces of Turkey was chosen as a studying area. The annual average daily temperature values of 13 meteorological stations in the region were used. For a broiler house, heating and cooling degree-day values and day numbers were calculated according to the based temperature values. Relationships between heating degree-day values, cooling degree-day values and degree-day numbers calculated according to the based temperature values were investigated by the linear regression analysis. As a result, it was determined upon an evaluation of the calculated heating degree-day, heating degree-day number, cooling degree-day and cooling degree-day number values that the cities of Aksaray, Ankara, Karaman, Kirikkale and Konya are most suited for broiler breeding.
\end{abstract}

Keywords: degree-day, heating, cooling, central Anatolia, broiler.

\section{Introduction}

Nutritional requirements that increase parallel to the increasing population of Turkey result in an increase in the production of animal and plant production. However, the expansion of settlement areas as a result of building more residential spaces has shed light on the fact that the space used for agriculture and animal husbandry has to decrease. In addition, the increase of production costs is considered by animal husbandry businesses as a significant problem. Today, poultry breeding is in demand for overcoming this problem and for providing healthy and cheap foods. The leading countries in poultry meat and products production can be listed in order as the USA (17.5 million tons), People's Republic of China (13 million tons) and Brazil (12 million tons). The share of the top ten producers of poultry meat and products in the world is $62 \%$ and Turkey meets a $1.8 \%$ portion of this total value [1]. As is the case in other animal breeding fields, the main objective of poultry husbandry is to obtain the highest and most economic yield for a certain cost. This depends on raising breeds that consume less fodder and have higher yield as well as improving the environmental conditions that they live in. It is necessary for a good production that the poultry housing interior should always be at the same temperature and should be controllable. Environmental control is an important factor for acquiring the desired yield. Both the environmental temperature and the air quality factors of the environment that the animals are kept in should be under control [2].

It is indicated in the studies carried out that the required technical principles and climate conditions of the region are not sufficiently taken into consideration, when positioning the poultry housings and the sizing of the structural elements [3]. Such shortcomings of the barns in our country have been determined by various studies carried out. These shortcomings that are observed especially in housings, where traditional production is carried out, are important for calculation of the energy consumption capacity. It is indicated that the energy expenses are an important factor for agricultural establishments that carry out different productions [4]. Therefore, having previous knowledge of the energy expenses for an animal shelter or an agricultural structure that will be built in a certain region shall be effective for the planning stage of agricultural structures. Heating or cooling degree-day values is a criterion used for determining the heating and cooling energy demands of buildings. This method assumes that the energy demand for a building is proportional to the difference between the average daily temperature and the selected basic temperature value [5]. Bayram and Yesilata [6] carried out a study, in which they put forth that determining the heating degree-day $(H D D)$ and 
cooling degree-day (CDD) values separately for a certain region is important for determining the capacity and costs of both the heating and cooling systems.

The objective of this study was to calculate the heating and cooling degree-days and numbers for broiler husbandry in Anatolia and to determine the best regions suited to broiler husbandry. For this purpose, the basic temperature suggested for broiler husbandry and the average long term temperature values for the cities included in the study have been used to calculate the heating and cooling degreeday values and numbers.

\section{Materials and methods}

The long-period average temperature values of the provinces (Ankara, Aksaray, Cankiri, Eskisehir, Kayseri, Kirikkale, Kırsehir, Nigde, Nevsehir, Karaman, Konya, Sivas, Yozgat cities) in the study area and recommended base temperature values for broiler chickens were the material of the study. The basic temperature values based on six-weekly growing periods of broiler chickens are given in Table 1 [7-10].

\section{Recommended weekly base temperature for broiler chicken}

Table 1

\begin{tabular}{|c|c|}
\hline Weeks & Base Temperature, ${ }^{\mathbf{0}} \mathbf{C}$ \\
\hline 1 & 31 \\
\hline 2 & 27 \\
\hline 3 & 25 \\
\hline 4 & 23 \\
\hline 5 & 21 \\
\hline 6 & 18 \\
\hline
\end{tabular}

Heating Degree-Day $(\boldsymbol{H D D}): H D D$ values are calculated by comparing the average outside temperature value with the recommended base temperature value [11]. The HDD value can be calculated by the following equations.

$$
H D D=\sum_{i=1}^{n}\left(\frac{T_{\max }+T_{\min }}{2}-T_{b}\right) \text { or } H D D=\sum_{i=1}^{n}\left(T_{\text {avg }}-T_{b}\right)
$$

where $T_{\max }$ - daily maximum temperature value, ${ }^{\circ} \mathrm{C}$;

$T_{\min }$ - daily minimum temperature value, ${ }^{\circ} \mathrm{C}$;

$T_{b}-$ recommended base temperature, ${ }^{\circ} \mathrm{C}$;

$n-$ the number of days in a year.

If the value of $\left(T_{\max }+T_{\min }\right) / 2$ in Equation 1 is greater than or equal to $T_{b}$, the heating degree-day $(H D G)$ value is calculated [12-14].

Cooling Degree-Day $(\boldsymbol{C D D}): C D D$ values are calculated by comparing the average outside temperature value with the recommended base temperature value [11]. The $C D D$ value can be calculated by the following equations.

$$
C D D=\sum_{i=1}^{n}\left(T_{b}-\frac{T_{\max }+T_{\min }}{2}\right) \text { or } C D D=\sum_{i=1}^{n}\left(T_{b}-T_{\text {avg }}\right)
$$

If the value of $\left(T_{\max }+T_{\min }\right) / 2$ in Equation 2 is smaller than $T_{b}$, the $C D D$ value is calculated [13-15].

Heating Degree-Day Number (HDDN): For a given time (such as days, months, seasons, years), the heating calculated from Equation 1 shows the total time the $H D D$ values were calculated. The $H D D N$ value can be calculated by Equation 3 .

$$
H D D N=\sum_{i=1}^{n} H D D
$$

where $H D D-$ heating degree-day value, ${ }^{\circ} \mathrm{C} \cdot$ day $[13 ; 14 ; 16]$. 
Cooling Degree-Day Number $(C D D N)$ : For a given time (such as days, months, seasons, years), the heating calculated from Equation 2 shows the total time the $C D D$ values were calculated. The $C D D N$ value can be calculated by Equation 4 .

$$
C D D N=\sum_{i=1}^{n} C D D
$$

where $C D D-$ cooling degree-day valu , ${ }^{\circ} \mathrm{C} \cdot$ day $[13 ; 14 ; 16]$.

\section{Results and discussion}

Broiler breeding is more sensitive in comparison with other forms of animal breeding. Therefore, heating and cooling or air-conditioning are more important. In this study, the $H D D$ and $C D D$ values and numbers in 13 cities in the Central Anatolia Region have been calculated in accordance with the suggested equations. Heating and cooling degree-day values and numbers were calculated using the average long term temperature values for the cities included in the study, which were acquired from the related meteorological stations as well as the base temperature values suggested for broilers (Figure 1).
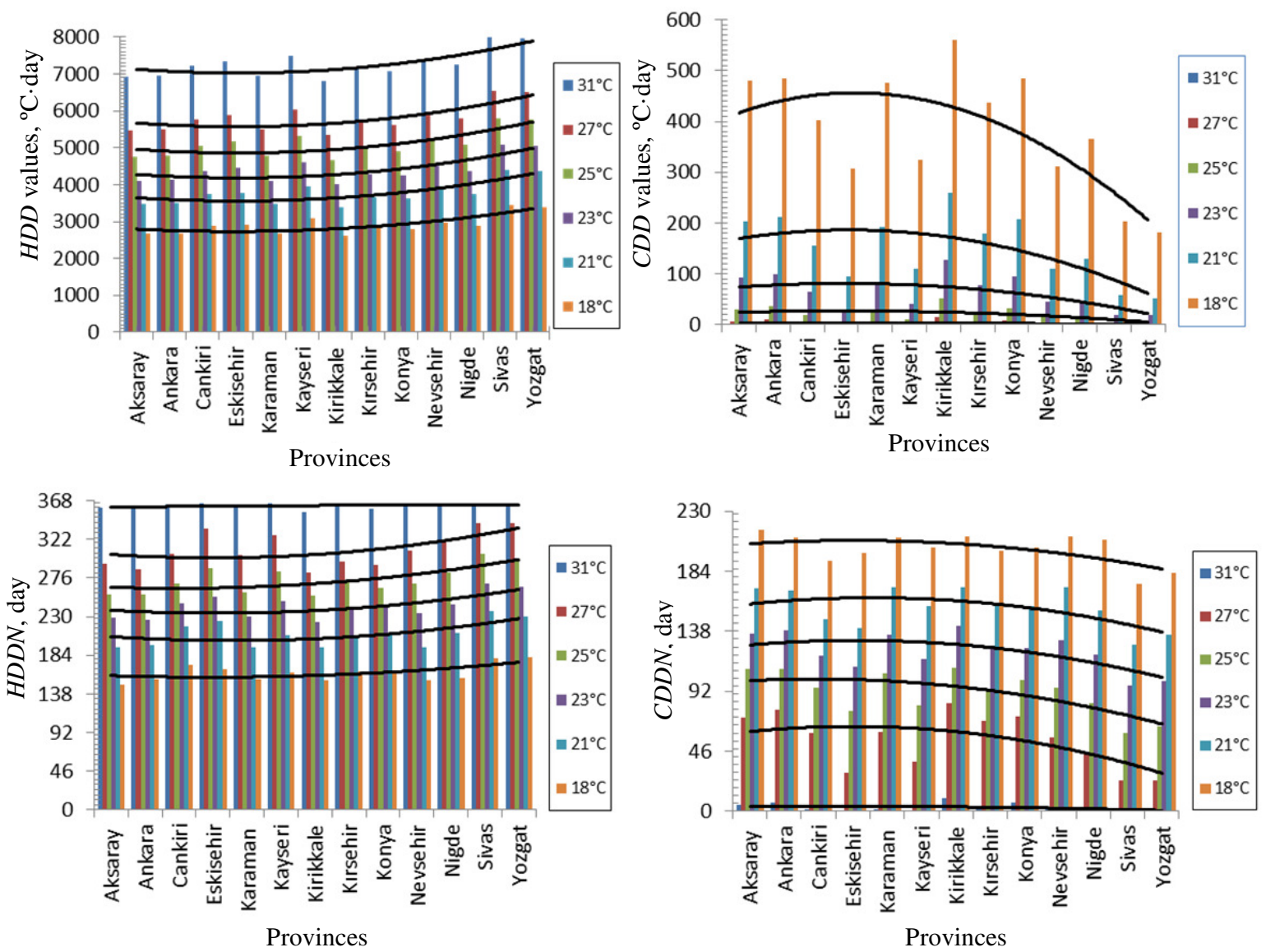

Fig. 1. Heating and cooling degree-day values and numbers of study area

It has been determined that the local conditions play a primary role on the heating and cooling degree-day values, that the $H D D$ values increase, while the $C D D$ values decrease at locations with higher continentality and elevation values. Accordingly, geography and orogpraphy are among the primary factors for determining the climate conditions in a certain region. Thus, different climate conditions can be experienced in the study region [17].

It was determined upon examining Figure 1 that Kayseri, Yozgat and Sivas are the cities, which require more heating in the region with regard to the $H D D$ values, while the city with the least heating requirement is Kirikkale and that the city with the highest cooling requirement is Kirikkale according to the $C D D$ values, while Yozgat and Sivas are the cities, which require the least amount of cooling. In addition, it has also been determined that Kirikkale and Aksaray are the cities in the region, which 
require the least heating according to the $H D D$ numbers, while Yozgat, Kayseri and Sivas are the cities, which require highest heating. Kirikkale was determined as the city, which requires the highest cooling according to the $C D D$ numbers, while Yozgat and Sivas were determined as the cities, which require the least amount of cooling.

Having previous knowledge of the energy costs of an agricultural structure or a barn that is planned to be built in a certain region is important for calculating the heating and cooling energy capacities. Aydin et.al [18] carried out a study, in which they set forth that higher heating degree-day numbers for a certain region indicate higher heating requirement and similarly that higher cooling degree-day numbers for a region indicate a higher cooling requirement. Whereas Satman and Yalcinkaya [19] indicated that using the degree-day values is one of the most frequently used methods for determining the heating energy consumption estimates for the winter and cooling energy consumption estimates for the summer months in the air-conditioning industry. Therefore, such studies can be carried out for acquiring prior knowledge on the heating and cooling energy consumption estimates for a certain structure in any region.

The relationships between the calculated heating and cooling degree-day values (HDD and $C D D,{ }^{\circ} \mathrm{C}$-day) and the heating and cooling degree-day numbers ( $H D D N$ and $C D D N$, Day) have been analyzed via regression analysis. A linear equation has been developed for $H D D, H D D N$ and $C D D N$ values $(H D D=a+b T, H D D N=a+b T, C D D N=a+b T)$, while a two parameter parabolic equation has been developed for the $C D D$ values $\left(C D D=a+b T+c T^{2}\right)$ and the statistical values have been given in Table 2.

Table 2

Relations between calculated HDD, CDD, HDDN and CDDN values

\begin{tabular}{|c|c|c|c|c|}
\hline \multirow{2}{*}{ Provinces } & \multicolumn{3}{|c|}{ Equation coefficients } & \multirow{2}{*}{$\begin{array}{c}\text { Correlation coefficient } \\
r\end{array}$} \\
\hline & $a$ & $\boldsymbol{b}$ & $c$ & \\
\hline \multicolumn{5}{|c|}{ Heating Degree-Day Values, ${ }^{\circ} \mathrm{C} \cdot$ day } \\
\hline Aksaray & 330.2 & -3412.0 & & 0.998 \\
\hline Ankara & 329.9 & -3389.0 & & 0.998 \\
\hline Cankiri & 336.4 & -3290.0 & & 0.998 \\
\hline Eskisehir & 344.2 & -3396.0 & & 0.999 \\
\hline Karaman & 330.9 & -3422.0 & & 0.998 \\
\hline Kayseri & 342.5 & -3192.0 & & 0.998 \\
\hline Kirikkale & 323.8 & -3359.0 & & 0.997 \\
\hline Kirsehir & 333.7 & -3314.0 & & 0.998 \\
\hline Konya & 330.0 & -3270.0 & & 0.998 \\
\hline Nevsehir & 343.4 & -3306.0 & & 0.999 \\
\hline Nigde & 323.8 & -3359.0 & & 0.997 \\
\hline Sivas & 351.4 & -2952.0 & & 0.999 \\
\hline Yozgat & 330.0 & -3270.0 & & 0.998 \\
\hline \multicolumn{5}{|c|}{ Cooling Degree-Day Values, ${ }^{\circ} \mathrm{C} \cdot$ day } \\
\hline Aksaray & 3709.0 & -264.1 & 4.671 & 0.996 \\
\hline Ankara & 3661.0 & -259.4 & 4.568 & 0.996 \\
\hline Cankırı & 3208.0 & -230.7 & 4.117 & 0.993 \\
\hline Eskisehir & 2597.0 & -190.3 & 3.450 & 0.984 \\
\hline Karaman & 3767.0 & -270.1 & 4.806 & 0.994 \\
\hline Kayseri & 2683.0 & -195.1 & 3.514 & 0.988 \\
\hline Kirikkale & 4122.0 & -289.5 & 5.059 & 0.997 \\
\hline Kirsehir & 3407.0 & -243.5 & 4.322 & 0.994 \\
\hline Konya & 3711.0 & -263.8 & 4.664 & 0.996 \\
\hline Nevsehir & 2510.0 & -181.6 & 3.256 & 0.989 \\
\hline Nigde & 4122.0 & -289.5 & 5.059 & 0.997 \\
\hline Sivas & 1715.0 & -125.8 & 2.284 & 0.981 \\
\hline Yozgat & 3711.0 & -203.8 & 4.661 & 0.996 \\
\hline
\end{tabular}


Table 2 (continued)

\begin{tabular}{|c|c|c|c|}
\hline \multirow{2}{*}{ Provinces } & \multicolumn{2}{|c|}{ Equation coefficients } & \multirow{2}{*}{$\begin{array}{c}\text { Correlation coefficient } \\
r\end{array}$} \\
\hline & $a$ & $\boldsymbol{b}$ & \\
\hline \multicolumn{4}{|c|}{ Heating Degree-Day Number (Day) } \\
\hline Aksaray & 16.24 & -145.7 & 0.999 \\
\hline Ankara & 15.57 & -130.0 & 0.998 \\
\hline Cankiri & 14.55 & -89.16 & 0.999 \\
\hline Eskisehir & 15.68 & -106.9 & 0.988 \\
\hline Karaman & 16.42 & -146.3 & 0.997 \\
\hline Kayseri & 16.25 & -127.0 & 0.992 \\
\hline Kirikkale & 15.41 & -129.9 & 0.997 \\
\hline Kirsehir & 15.12 & -108.6 & 0.999 \\
\hline Konya & 14.78 & -103.1 & 0.999 \\
\hline Nevsehir & 16.63 & -148.4 & 0.997 \\
\hline Nigde & 16.34 & -131.7 & 0.995 \\
\hline Sivas & 14.63 & -70.62 & 0.981 \\
\hline Yozgat & 14.72 & -75.52 & 0.983 \\
\hline \multicolumn{4}{|c|}{ Cooling Degree-Day Number (Day) } \\
\hline Aksaray & -16.24 & 510.7 & 0.999 \\
\hline Ankara & -15.57 & 495.0 & 0.998 \\
\hline Cankiri & -14.55 & 454.1 & 0.999 \\
\hline Eskişehir & -15.68 & 471.8 & 0.988 \\
\hline Karaman & -16.42 & 511.3 & 0.997 \\
\hline Kayseri & -16.25 & 492.0 & 0.992 \\
\hline Kirikkale & -15.41 & 493.9 & 0.997 \\
\hline Kirsehir & -15.12 & 473.6 & 0.996 \\
\hline Konya & -14.78 & 468.1 & 0.996 \\
\hline Nevsehir & -16.63 & 513.4 & 0.997 \\
\hline Nigde & -16.34 & 496.7 & 0.995 \\
\hline Sivas & -14.04 & 419.7 & 0.984 \\
\hline Yozgat & -14.72 & 440.5 & 0.983 \\
\hline
\end{tabular}

It was determined upon examining Table 2 that the cities in the region with the least amount of change in the $H D D$ values were Kirikkale and Nigde respectively, while Yozgat had the highest change; whereas Sivas had the lowest change with regard to $C D D$ values and Kirikkale and Nigde had the highest change. It was determined that the least amount change with regard to $H D D N$ values was in the city of Cankiri, while the highest change was in the city of Nevsehir, while the least amount of change with regard to $C D D N$ values was in the city of Sivas, while the highest change was in the city of Nevsehir. It was thought that the changes in the values of $H D D$ and $H D D N$ along with $C D D$ and $C D D N$ may not be dependent only on temperature, but also on factors of local geography and orography. In general; it was determined that the HDD values in the region had a tendency to increase linearly between the values of 323.8-351.4, while there was a tendency in the $C D D$ values to decrease parabolically in the 125.8-289 interval. While it was determined that the HDDN values had a tendency to increase linearly in the 14.63-16.63 interval, while the $C D D N$ values had a tendency to decrease linearly in the 125.8-289.5 interval. The fact that the study area has a continental climate along with longer winter seasons increases heating energy consumption. As a result, it was determined upon an evaluation of the calculated $H D D, H D D N, C D D$ and $C D D N$ values that the cities of Aksaray, Ankara, Karaman, Kirikkale and Konya are most suited for broiler breeding.

\section{Conclusions}

Heating and cooling degree-days and numbers were calculated for the 13 cities in the study region using the long term annual meteorological data along with the six week base temperature values for broilers. In line with the calculated degree-day values, the places that are most suited for broiler breeding in the study region were determined. In this regard, it was concluded that the cities of Aksaray, Ankara, Karaman, Kirikkale and Konya were most suited for broiler breeding in the region. It was also concluded that calculating the heating and cooling degree-day values for any barn, poultry 
house or structure to be constructed in any region shall contribute to the planning stage for the energy consumption capacities of these structures.

\section{References}

[1] Poultry Meat Sector, Republic of Turkey Ministry of Economy Sector Reports, General Directorate of Export General Directorate of Agricultural Products, 2017, https://www.ekonomi.gov.tr/portal/content/conn/UCM/uuid/dDocName:EK-235406. (In Turkish)

[2] Gurdil A.K.G., Yildiz Y. A Research on Developing A Program for Designing Ventilation Systems in Poultry Houses, Cukurova University Institute of Sciences Publications, 2004, [online][11.03.2018] Available at: http://fbe.cu.edu.tr/tr/makaleler/2004/kumeslerde.pdf. (In Turkish)

[3] Kocaman I. The Research on the Determination of Structural Properties of Poultry Houses and Improvement Facilities in Karaman, JOTAF/ Journal of Tekirdag Agricultural Faculty, 7(2), 2010, pp. 179-186. (In Turkish)

[4] Demircan V., Koyuncu M.A. Economic Analysis of Different Cold Storage Types: A Case Study of Isparta Province, Turkey. Scientific Papers Series Management, Economic Engineering in Agriculture and Rural Development, 17(2), 2017, pp.85-94.

[5] Buyukalaca O., Bulut H., Yilmaz T. Analysis of variable-base heating and cooling degree-days for Turkey, Applied Energy, vol. 69, 2001, pp. 269-283.

[6] Bayram M., Yesilata B. Integration of Number of Heating and Cooling Degree Days, IX. National Plumbing Engineering Congress, 6-9 May, Izmir, 2009, pp. 425-432.

[7] Lindley J.A., Whitaker J.H. Agricultural buildings and structures. 2nd edn. Technical Books Information Publishing Group, USA, 1996. 605 p.

[8] Atilgan A., Yucel A., Oz H. Determination of heating and cooling day data for broiler housing: Isparta case, Journal of Food, Agriculture \& Environment Vol.10 (3\&4), 2012, pp. 353-356.

[9] Animal Production, Education Ministry, [online] [16.01.2016] Available at: http://megep.meb.gov.tr (In Turkish)

[10] Broiler Production, Agriculture Ministry, [online][15.12.2015] Available at: http://www.tarim.gov.tr (In Turkish)

[11]Bulut, H., Buyukalaca, O., Yilmaz, T. Heating and Cooling Degree Days-Regions for Turkey, ULIBTK'07 16. National Congress of Heat Science and Technology, 30 May-2 June 2007, Kayseri. (In Turkish)

[12] Heerdegen R. G. An Evaluation of the Heating Degree-Day Index, Weather and Climate, 8, 1988, pp. 69-75.

[13] Borah P., Singh M. K., Mahapatra S. Estimation of Degree-Days for Different Climatic Zones of North-East India, Sustainable Cities and Society, 14, 2015, pp. 70-81.

[14] Indragandi M., Boussaa D. A Method to Estimate The Heating And Cooling Degree-Days For Different Climatic Zones of Saudi Arabia, Building Services Engineering Research \& Technology, 38(3), 2017, pp. 327-350.

[15] Krese G., Prek M., Butala V. Analysis of building electric energy consumption data using an improved cooling degree day method, Journal of Mechanical Engineering, vol. 58(2), 2012, pp. 107-114.

[16] Gulten A. Ekici B.B. Estimation of Optimum Isolation Thickness Changing According to The Number of Heating and Cooling Days, 2nd International Sustainable Buildings Symposium, ISBS, 28-30 May 2015, pp. 854-857, Ankara, Turkiye. (In Turkish)

[17] Bahadir M., Uzun A., Zeybek H. I., Hatipoglu I. K. Heating and Cooling Degree-Days Analysis and Annual Heating Cost Calculation for Samsun Province, International Journal of Social Science, 46, 2016, pp. 173-185. (In Turkish)

[18] Aydin D., Kavak A.F., Toros H. The impact on electricity consumption of heating and cooling degree days. VII. Atmospheric Science Symposium, April 28-30, Istanbul, 2015, pp. 29-39.

[19] Satman A., Yalcinkaya, N. Heating and cooling degree-hours for Turkey, Energy 24, 1999, pp. 833-840. 